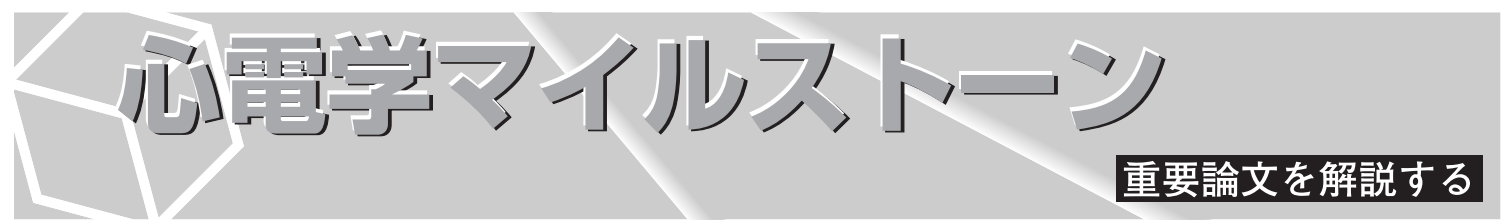

\title{
大草知子 (山口大学大学院医学系研究科器官病態内科学循環器内科)
}

The cardiac desmosome and arrhytomogenic cardiomyopathies : from gene to disease.

Delmar M, McKenna WJ

Circ Res, $2010 ; 107: 700 \sim 714$

隣接する心筋細胞間は介在板により結合さ れ，介在板はgap junction (GJ) と adhesion junction $(\mathrm{AJ})$ で構成される。細胞間の電気的結 合は GJ, 機械的結合は AJ で維持され，心筋細 胞の同期的な収縮・弛緩を繰り返している，GJ は細胞間を直接連結するチャネルにより構成さ れ，コネキシン $(\mathrm{Cx})$ 蛋白の複合体からなる. GJ モデリングが重要な不整脈発生基盤である ことはよく知られている。一方, $\mathrm{AJ} は$ adherens junction とデスモソームで構成され, 細胞間の機械的結合を保持する役割を担ってお り, GJ と機能的・構造的に密接な関係を有して いる。 その構造は, リンカー蛋白質を介した細 胞膜貫通蛋白質と細胞骨格蛋白質の結合体で, 細胞の収縮・弛緩の同期性を維持している.

Naxos 病や Carvajal 症候群はそれぞれデスモ プラキンとプラコグロビンの異常により, 皮膚 や眼をはじめとする全身の結合組織の異常をき たす遺伝性疾患で，古くよりこれらは不整脈を 合併して突然死を起こすことが知られている. また，不整脈原性右室心筋症 $(\mathrm{ARVC})$ は，デス モソームを構成するプラコフィリン 2 (PKP2) などの構成蛋白質の遺伝子異常が原因と報告さ れている. 従来, 不整脈発生基盤として, 細胞 膜イオンチャネル， GJ, および $\mathrm{Ca}^{2+}$ ホメオスタ シスの研究は幅広く行われてきた。しかし, 不 整脈発生基盤としての GJ 以外の介在板構成蛋 白質リモデリングの解明はその構造，構成蛋白
質の複雑さからいまだ十分ではない。このよう な状況下で，その分野での第一人者である Dr. Mario Delmarによる, 待望の review 論文が発 表された。

本論文は，心筋細胞介在板，なかでもデスモ ソーム異常と催不整脈性 (特に ARVC) につき 詳細にわかりやすくまとめた“gene-to-disease” の reviewである. 冒頭ではデスモソームの構造, それを構成する各種蛋白質, その機能につき述 ベられている，続いて，デスモソームを構成す る各蛋白質ごとに, その異常と疾患 (Naxos 病, 天疮瘡，掌蹠角皮症など）の関連性につきまと められている。ささらに, これらの疾患が心臓突 然死を合併することや ARVC の多くがデスモ ソーム構成蛋白質 (PKP2P, デスモグレイン, デスモコリンなど) の遺伝子異常を合併してい ることに注目し，デスモソームとほかの介在板 構成蛋白である adherens junction や GJ との細 胞分子生物学的な文献的考察を加えつつ, デス モソーム異常を含む介在版リモデリングの催不 整脈性につき詳しくまとめられている.

不整脈発生基盤として, 細胞間結合構成蛋白 質の異常をわかりやすく概説した本論文は, 介 在板リモデリングを理解するうえで, 非常に有 用な論文と思われる。本論文でも言及している が, 今後は, 介在板リモデリングのさらなる研 究と, 不整脈の新しい治療法 (薬) 開発の推進が 期待される. 